\title{
Radioactive equilibria and disequilibria of U-series nuclides in the products from Izu arc volcanoes, Japan
}

\author{
By Y. Kurihara ${ }^{1, *}$, M. Takahashi ${ }^{2}$ and J. Sato ${ }^{1}$ \\ ${ }^{1}$ Department of Applied Chemistry, School of Science and Technology, Meiji University, Higashi-mita, Tama-ku, Kawasaki-shi, \\ Kanagawa Pref. 214-8571, Japan \\ 2 Radiation Safety Research Center, Nuclear Technology Research Laboratory, Central Research Institute of Electric Power Industry, Iwado Kita, \\ Komae-shi, Tokyo 201-5811, Japan
}

(Received November 11, 2009; accepted in revised form November 12, 2010)

Uranium series / Activity ratio / Equilibrium /

Disequilibrium / Volcanic rock / Izu arc

Summary. Activity ratios among ${ }^{238} \mathrm{U}-{ }^{230} \mathrm{Th}-{ }^{226} \mathrm{Ra}$ in the products from Izu arc volcanoes, Japan, were observed in order to estimate the time scale of magmatic processes and the magma generation for Izu arc volcanism. Activity ratios of ${ }^{238} \mathrm{U} /{ }^{230} \mathrm{Th}$ and ${ }^{226} \mathrm{Ra} /{ }^{230} \mathrm{Th}$ in the basaltic and andesitic products from Izu arc volcanoes were greater than unity, being enriched in ${ }^{238} \mathrm{U}$ and ${ }^{226} \mathrm{Ra}$ relative to ${ }^{230} \mathrm{Th}$. The ${ }^{226} \mathrm{Ra} /{ }^{230} \mathrm{Th}$ activity ratio versus ${ }^{238} \mathrm{U} /{ }^{230} \mathrm{Th}$ activity ratio diagram for these products showed positive correlation, suggesting that the ${ }^{238} \mathrm{U}-{ }^{230} \mathrm{Th}-{ }^{226} \mathrm{Ra}$ disequilibria occurred during the magma genesis by the additions of $\mathrm{U}$ - and Ra-rich fluids derived from the subducting slab by dehydration to the mantle wedge. The ${ }^{230} \mathrm{Th}-{ }^{226} \mathrm{Ra}$ radioactive disequilibria observed in the basaltic and andesitic products imply a short period of time $(<8000$ years) between the magma genesis and the eruption. The majority of rhyolitic products was considered to be almost in equilibrium of ${ }^{238} \mathrm{U}={ }^{230} \mathrm{Th}={ }^{226} \mathrm{Ra}$. The observation that ${ }^{238} \mathrm{U}-{ }^{230} \mathrm{Th}-{ }^{226} \mathrm{Ra}$ for the rhyolite are in radioactive equilibrium suggested that the rhyolitic magma from Izu arc was generated in the partial melting of the earth crust heated by the basaltic magma of high temperature.

\section{Introduction}

The decay chain of ${ }^{238} \mathrm{U}\left(t_{1 / 2}=4.5 \times 10^{9} \mathrm{y}\right)$ contains a number of radioactive nuclides with different chemical properties and half-lives. During magmatic processes from the magma generation in the mantle to the eruption, the differences in chemical properties between parent and daughter nuclides will allow them to be fractionated, generating radioactive disequilibrium. As the time since the fractionation can be assessed using the half-lives of the daughter nuclides $\left(\right.$ e.g., $t_{1 / 2}=7.5 \times 10^{4} \mathrm{y}$ for ${ }^{230} \mathrm{Th}$, and $t_{1 / 2}=$ $1.6 \times 10^{3} \mathrm{y}$ for ${ }^{226} \mathrm{Ra}$ ), investigations of radioactive disequilibria among U-series nuclides in volcanic rocks can potentially provide the information on the time scale of magmatic processes [1]. While the ${ }^{238} \mathrm{U}-{ }^{230} \mathrm{Th}$ disequilibria can be used to estimate the time scale of an event of

\footnotetext{
*Author for correspondence (E-mail: uichi@isc.meiji.ac.jp).
}

the $\mathrm{U}-\mathrm{Th}$ fractionation within the period of $3.5 \times 10^{5} \mathrm{y}$ (i.e., 5 half-lives yield $97 \%$ of the equilibrium), the ${ }^{230} \mathrm{Th}-{ }^{226} \mathrm{Ra}$ disequilibria can be used to estimate the time scale of an event of the $\mathrm{Th}-\mathrm{Ra}$ fractionation within the period of $8.0 \times 10^{3} \mathrm{y}$.

The generation of arc magmas is generally inferred to be induced by the partial melting of the mantle wedge by the addition of the fluid derived from the subducting slab [2].

The majority of the arc volcanic rocks is characterized by ${ }^{238} \mathrm{U}$-excess over ${ }^{230} \mathrm{Th}[3,4]$. Because $\mathrm{U}$ and Ra are highly mobile element in aqueous fluids relative to Th $[5,6]$, the excess of ${ }^{238} \mathrm{U}$ over ${ }^{230} \mathrm{Th}$ in the arc volcanic rocks has generally been ascribed to the addition of U-rich fluids derived from the subducting slab by dehydration.

The investigations of the disequilibria between ${ }^{230} \mathrm{Th}$ and ${ }^{226} \mathrm{Ra}$ in fresh volcanic rocks from many arcs have shown that the majority of arc volcanic rocks are characterized by ${ }^{226} \mathrm{Ra}$ excess over ${ }^{230} \mathrm{Th}[3,4]$. The ${ }^{230} \mathrm{Th}-{ }^{226} \mathrm{Ra}$ disequilibria observed in the most arc volcanic rocks along with the positive correlations with ${ }^{238} \mathrm{U} /{ }^{230} \mathrm{Th}$ activity ratio and $\mathrm{Ba} / \mathrm{Th}$ concentration ratio (the latter is usually regarded as a good indicator of the fluid addition) may also be attributed to the addition of U- and Ra-rich fluids derived from the subducting slab by dehydration, implying that the time scale from the magma genesis to the eruption was less than $8.0 \times 10^{3} \mathrm{y}$.

The ${ }^{238} \mathrm{U}-{ }^{230} \mathrm{Th}$ disequilibria in the products from Izu arc volcanoes have previously been observed [7-11]. The observations showed that while the ${ }^{230} \mathrm{Th} /{ }^{238} \mathrm{U}$ activity ratios of basaltic and andesitic products were smaller than unity, being enriched in ${ }^{238} \mathrm{U}$ relative to ${ }^{230} \mathrm{Th}[7-10]$, the ${ }^{230} \mathrm{Th} /{ }^{238} \mathrm{U}$ activity ratios of rhyolitic products were considered to be almost unity [11].

As the prior studies of radioactive disequilibrium between ${ }^{230} \mathrm{Th}$ and ${ }^{226} \mathrm{Ra}$ in the basaltic products from Izu arc volcanoes were limited $[12,13]$, although Miyake-jima volcano has been intensively investigated $[7,8],{ }^{226} \mathrm{Ra}$ in the basaltic products from Fuji and Izu-Oshima volcanoes located along Izu arc are presently measured.

This report deals with the discussion including the latest observations of the ${ }^{226} \mathrm{Ra} /{ }^{230} \mathrm{Th}$ activity ratio in the basaltic products from Fuji and Izu-Oshima volcanoes, which belong to Izu arc in order to estimate the time scale of magmatic 


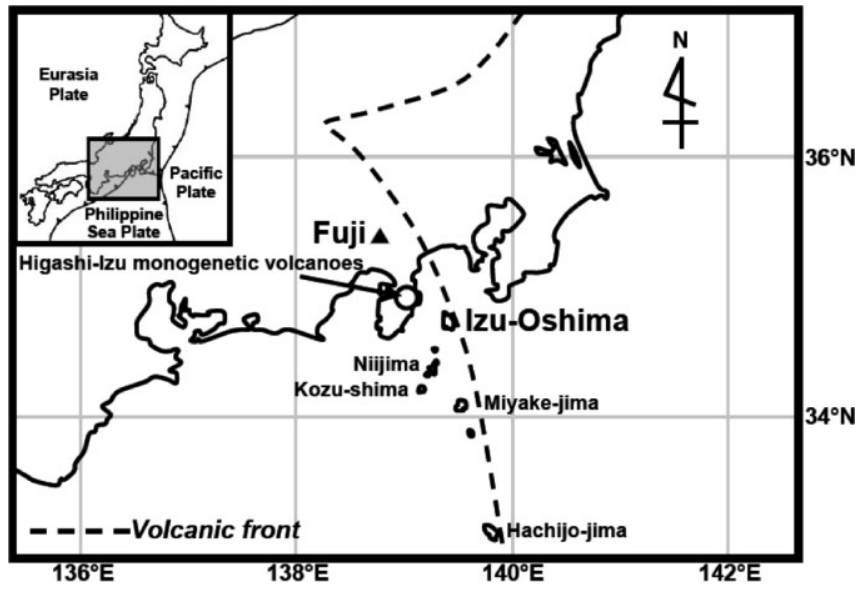

Fig. 1. Locality map of Izu arc volcanoes, Japan.

processes. Discussion will extend to the comparison with the activity ratio of the rhyolitic products [14] from Izu arc volcanoes.

\section{Samples and analytical methods}

\section{Samples}

Observations were carried out with 16 volcanic rock samples from Fuji (800-802 AD, 864-866 AD, 937 AD and $1033 \mathrm{AD}$ ) and Izu-Oshima (9th C, $1338 \mathrm{AD}, 1421 \mathrm{AD}$, $1552 \mathrm{AD}, 1684 \mathrm{AD}, 1777-1778 \mathrm{AD}$ and 1950-1951 AD) volcanoes located along Izu arc, Japan. For 6 volcanic rock samples of these samples, $\mathrm{U}$ and $\mathrm{Th}$ isotopes were also measured (Table 1). Locality map is shown in Fig. 1.

\section{Analytical methods}

$\mathrm{SiO}_{2}$ concentration in the volcanic rock samples was determined by X-ray fluorescence spectrometry (XRF) using fused glass beads made by mixing sample with anhydrous lithium tetraborate as a flux. The experimental procedures have been described in detail by Nakayama and Nakamura [15].

Determination of $\mathrm{U}$ and $\mathrm{Th}$ isotopes in the volcanic rock sample was made by an isotope dilution analysis coupled with $\alpha$-ray spectrometry. Uranium-232 was spiked for determination of $U$ isotopes and commercially available Th reagent having different ${ }^{230} \mathrm{Th} /{ }^{232} \mathrm{Th}$ activity ratio from those in the volcanic rock samples was spiked for determination of Th isotopes. Detailed chemical separation and purification procedures of $\mathrm{U}$ and $\mathrm{Th}$ isotopes from the lava samples have previously been described in Takahashi et al. [16]. The purified $\mathrm{U}$ and $\mathrm{Th}$ fractions were electrodeposited onto stainless steel planchets of 1 inch $\varnothing$ by Lee's method [17] for $\alpha$-ray counting, respectively.

Determination of ${ }^{226} \mathrm{Ra}$ in the volcanic rock samples was made by non-destructive $\gamma$-ray spectrometry. About $100 \mathrm{~g}$ of volcanic rock sample was packed into a canister of tin-can (76 $\mathrm{mm} \varnothing, 24 \mathrm{~mm}$ high). The canister was sealed with epoxy resin (Araldite ${ }^{\circledR}$ ) completely. The volcanic rock sample for the $\gamma$-ray measurement thus prepared was stored for 1 month in order that ${ }^{214} \mathrm{~Pb}$ reached the equilibrium with ${ }^{226} \mathrm{Ra}$ within the canister.

Table 1. $\mathrm{SiO}_{2}$ contents, $\mathrm{U}-\mathrm{Th}-\mathrm{Ra}$ data for the historical eruption products from Fuji and Izu-Oshima volcanoes.

\begin{tabular}{|c|c|c|c|c|c|c|c|}
\hline \multirow{2}{*}{$\begin{array}{l}\text { Volcano } \\
\text { (Eruption year) }\end{array}$} & \multirow[t]{2}{*}{ Sample identification } & \multicolumn{3}{|c|}{ Content } & \multicolumn{3}{|c|}{ Activity ratio } \\
\hline & & $\begin{array}{l}\mathrm{SiO}_{2} \\
{[\%]}\end{array}$ & $\mathrm{U}_{\left[\mu \mathrm{g} \cdot \mathrm{g}^{-1}\right]}^{\mathrm{Th}}$ & $\begin{array}{c}{ }^{226} \mathrm{Ra} \\
{\left[\mathrm{fg} \cdot \mathrm{g}^{-1}\right]}\end{array}$ & ${ }^{234} \mathrm{U} /{ }^{238} \mathrm{U}$ & ${ }^{238} \mathrm{U} /{ }^{232} \mathrm{Th} \quad{ }^{230} \mathrm{Th} /{ }^{232} \mathrm{Th}$ & ${ }^{226} \mathrm{Ra} /{ }^{230} \mathrm{Th}$ \\
\hline
\end{tabular}

Fuji

(800-802 AD)

(864-866 AD)

(937 AD)

(1033 AD)

Izu-Oshima

(9th C)

(1338 AD)

(1421 AD)

(1552 AD)

(1684 AD)

(1777-1778 AD)

(1950-1951 AD)
Tak-1 96080901 ${ }^{a}$

Ao- $95122802^{a}$

Ao-95120814 ${ }^{c}$

Ao-95101905 ${ }^{c}$

Ao- $95120811^{c}$

Ao- $95060308^{c}$

Ken-6 96080908 ${ }^{a}$

Ken-5 $96080907^{\circ}$

$$
\begin{array}{ccc}
49.3(0.1)^{b} & 0.49 \pm 0.02 & 1.17 \pm 0.06 \\
49.7(0.1)^{b} & 0.55 \pm 0.02 & 1.33 \pm 0.09 \\
- & 0.58 \pm 0.02 & 1.34 \pm 0.04 \\
- & 0.56 \pm 0.02 & 1.48 \pm 0.05 \\
- & 0.58 \pm 0.03 & 1.36 \pm 0.08 \\
- & 0.49 \pm 0.02 & 1.30 \pm 0.05
\end{array}
$$

$\begin{array}{llll}49.8 & (0.1)^{b} & 0.43 \pm 0.02 & 1.14 \pm 0.05\end{array}$

$50.3(0.1)^{b} \quad 0.44 \pm 0.01 \quad 1.08 \pm 0.06$

$\begin{array}{lll}220 \pm 6 & 1.01 \pm 0.02 & 1.30 \pm 0.08 \\ 212 \pm 6 & 0.98 \pm 0.02 & 1.24 \pm 0.09 \\ 229 \pm 6 & 0.98 \pm 0.02 & 1.31 \pm 0.06 \\ 224 \pm 7 & 1.02 \pm 0.02 & 1.18 \pm 0.06 \\ 221 \pm 9 & 0.99 \pm 0.02 & 1.29 \pm 0.09 \\ 206 \pm 5 & 1.01 \pm 0.02 & 1.18 \pm 0.06 \\ 176 \pm 4 & 1.00 \pm 0.02 & 1.16 \pm 0.07 \\ 199 \pm 6 & 0.98 \pm 0.02 & 1.15 \pm 0.07\end{array}$

$1.09 \pm 0.02$

$1.06 \pm 0.03$

$1.06 \pm 0.01$

$1.04 \pm 0.01$

$1.06 \pm 0.02$

$1.04 \pm 0.01$

$1.08 \pm 0.02$

$1.06 \pm 0.02$
$1.56 \pm 0.09$

$1.36 \pm 0.11$

$1.46 \pm 0.06$

$1.32 \pm 0.06$

$1.38 \pm 0.10$

$1.38 \pm 0.06$

$1.29 \pm 0.07$

$1.60 \pm 0.10$

a: Uranium and Th data are taken from Table 2 of [9];

b: Relative standard deviation / $\%, n=5$;

c: Uranium and Th data are obtained in this work.

$\begin{array}{lllll}64 \pm 3 & 1.01 \pm 0.01 & 1.99 \pm 0.10 & 1.53 \pm 0.03 & 1.36 \pm 0.10 \\ 73 \pm 3 & 1.00 \pm 0.02 & 1.52 \pm 0.08 & 1.24 \pm 0.02 & 1.31 \pm 0.09 \\ 86 \pm 6 & 1.01 \pm 0.02 & 1.79 \pm 0.08 & 1.36 \pm 0.02 & 1.68 \pm 0.13 \\ 77 \pm 3 & 1.00 \pm 0.02 & 1.99 \pm 0.09 & 1.41 \pm 0.02 & 1.63 \pm 0.10 \\ 60 \pm 3 & 1.01 \pm 0.02 & 2.00 \pm 0.10 & 1.35 \pm 0.02 & 1.25 \pm 0.08 \\ 85 \pm 3 & 0.99 \pm 0.02 & 1.61 \pm 0.11 & 1.38 \pm 0.05 & 1.61 \pm 0.11 \\ 78 \pm 5 & 1.00 \pm 0.03 & 1.55 \pm 0.10 & 1.38 \pm 0.03 & 1.58 \pm 0.14 \\ 86 \pm 5 & 1.01 \pm 0.03 & 2.21 \pm 0.16 & 1.41 \pm 0.02 & 2.14 \pm 0.19\end{array}$

$86 \pm 5$ $\begin{array}{llll}50.8 & (0.1)^{b} & 0.18 \pm 0.00 & 0.28 \pm 0.01\end{array}$ $\begin{array}{llll}52.1 & (0.1)^{b} & 0.20 \pm 0.01 & 0.40 \pm 0.02\end{array}$

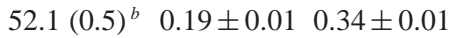
$\begin{array}{llll}51.9 & (0.5)^{b} & 0.20 \pm 0.01 & 0.31 \pm 0.01\end{array}$ $\begin{array}{lll}51.5(0.1)^{b} & 0.21 \pm 0.01 & 0.32 \pm 0.01\end{array}$ $\begin{array}{lll}52.5(0.1)^{b} & 0.18 \pm 0.01 & 0.33 \pm 0.02\end{array}$ $\begin{array}{lll}50.2(0.3)^{b} & 0.16 \pm 0.01 & 0.32 \pm 0.02\end{array}$

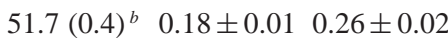




\section{Radioactivity measurement}

Activity ratios of $U$ and Th isotopes were obtained by $\alpha$-ray spectrometry using a $900 \mathrm{~mm}^{2}$ PIPS detector (CANBERRA, A 900-25 AB) coupled with an MCA system (Laboratory Equipment; ADC 2201A). Radioactivities of $U$ and Th isotopes were determined by the following $\alpha$-rays: $4.151 \mathrm{MeV}$ and $4.198 \mathrm{MeV}$ for ${ }^{238} \mathrm{U}, 4.722 \mathrm{MeV}$ and $4.775 \mathrm{MeV}$ for ${ }^{234} \mathrm{U}, 5.263 \mathrm{MeV}$ and $5.320 \mathrm{MeV}$ for ${ }^{232} \mathrm{U}, 3.954 \mathrm{MeV}$ and $4.013 \mathrm{MeV}$ for ${ }^{232} \mathrm{Th}$, and $4.621 \mathrm{MeV}$ and $4.688 \mathrm{MeV}$ for ${ }^{230} \mathrm{Th}$, respectively.

Gamma-ray intensity was measured with an HPGe semiconductor detector (Princeton Gamma-Tec, IGC-10200 NPR) coupled with an MCA system (Aptec Engineering, 5008). Radioactivity of ${ }^{226} \mathrm{Ra}$ was determined by the $351.9 \mathrm{keV} \gamma$-ray from ${ }^{214} \mathrm{~Pb}$ in equilibrium with ${ }^{226} \mathrm{Ra}$.

\section{Results and discussion}

The present determination procedures were applied to JB-1, the geochemical reference material of basalt, issued by Geological Survey of Japan (The National Institute of Advanced Industrial Science and Technology). The reference material should be in radioactive equilibrium among U-series nuclides, because the eruption age of JB-1 is $7.59 \mathrm{Ma}$ [18]. The activity ratios among ${ }^{238} \mathrm{U}-{ }^{234} \mathrm{U}-{ }^{230} \mathrm{Th}-{ }^{226} \mathrm{Ra}$ in JB-1 were observed to be unity.

Table 1 lists the contents of $\mathrm{U}$, Th (in $\mu \mathrm{g} \mathrm{g}^{-1}$ ) and ${ }^{226} \mathrm{Ra}$ (in $\mathrm{fg} \mathrm{g}^{-1}$ ) along with $\mathrm{SiO}_{2}$ content (in \%), and the activity ratios of ${ }^{234} \mathrm{U} /{ }^{238} \mathrm{U},{ }^{238} \mathrm{U} /{ }^{232} \mathrm{Th},{ }^{230} \mathrm{Th} /{ }^{232} \mathrm{Th}$ and ${ }^{226} \mathrm{Ra} /{ }^{230} \mathrm{Th}$ in the historical eruption products from Fuji and Izu-Oshima volcanoes.

As ${ }^{234} \mathrm{U}$ in the products has been reported to be in equilibrium with ${ }^{238} \mathrm{U}[9],{ }^{230} \mathrm{Th}$ in the products can be regarded as the direct decay product of ${ }^{238} \mathrm{U}$.

\section{Radioactive equilibria and disequilibria among ${ }^{238} \mathrm{U}-{ }^{230} \mathrm{Th}-{ }^{226} \mathrm{Ra}$ in the volcanic rock samples}

Fig. 2 is the $\left({ }^{230} \mathrm{Th} /{ }^{232} \mathrm{Th}\right)-\left({ }^{238} \mathrm{U} /{ }^{232} \mathrm{Th}\right)$ activity ratio diagram for the products from Izu arc volcanoes $[9,11]$.

While the majority of rhyolitic products was almost in radioactive equilibrium [11], the activity ratios of basaltic and andesitic products from Izu arc showed ${ }^{230} \mathrm{Th} /{ }^{238} \mathrm{U}<1$ [9]. The suite of $\left({ }^{230} \mathrm{Th} /{ }^{232} \mathrm{Th}\right)-\left({ }^{238} \mathrm{U} /{ }^{232} \mathrm{Th}\right)$ data for the basaltic and andesitic products [9] forms a broad inclined array which is similar to the data sets for Tonga-Kermadec [19] and Mariana [20] island arcs.

Fig. 3 is the $\left({ }^{226} \mathrm{Ra} /{ }^{230} \mathrm{Th}\right)_{0}$ activity ratio versus ${ }^{238} \mathrm{U} /$ ${ }^{230} \mathrm{Th}$ activity ratio diagram for the products [12-14]. $\left({ }^{226} \mathrm{Ra} /{ }^{230} \mathrm{Th}\right)_{0}$ represents the decay-corrected ${ }^{226} \mathrm{Ra} /{ }^{230} \mathrm{Th}$ value for ${ }^{226} \mathrm{Ra}$ to the eruption year.

The ${ }^{238} \mathrm{U} /{ }^{230} \mathrm{Th}$ and $\left({ }^{226} \mathrm{Ra} /{ }^{230} \mathrm{Th}\right)_{0}$ activity ratios of the products show a bimodal distribution: one is the basalt and andesdite group and the other is the rhyolite group [14]. The majority of rhyolitic products converges on the radioactive equilibrium point of ${ }^{230} \mathrm{Th}={ }^{226} \mathrm{Ra}$ and ${ }^{238} \mathrm{U}={ }^{230} \mathrm{Th}$. The observation that ${ }^{238} \mathrm{U}-{ }^{230} \mathrm{Th}-{ }^{226} \mathrm{Ra}$ for the rhyolite are in radioactive equilibrium suggested that the rhyolitic magma from Izu arc was generated in the partial melting of the

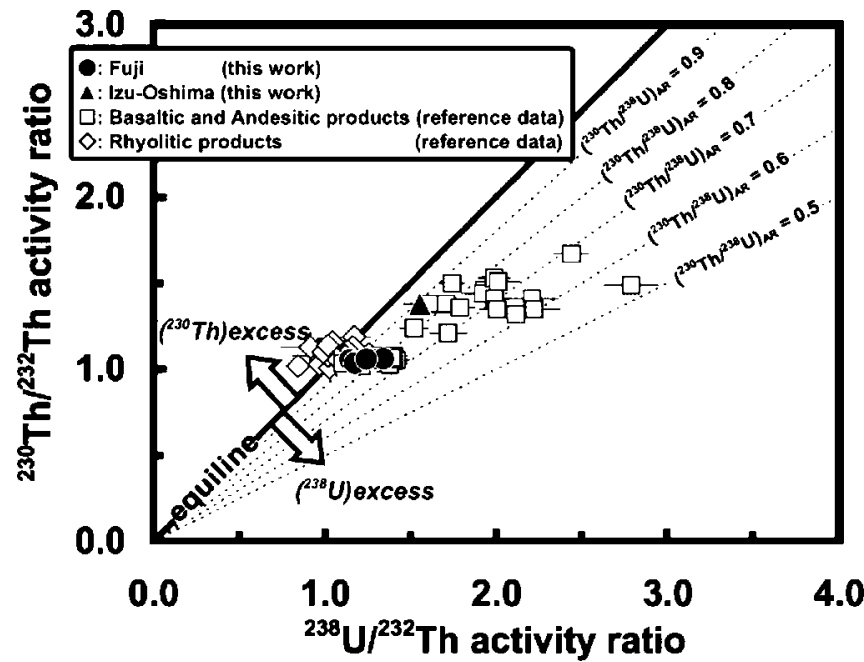

Fig. 2. ${ }^{230} \mathrm{Th} /{ }^{232} \mathrm{Th}$ activity ratio versus ${ }^{238} \mathrm{U} /{ }^{232} \mathrm{Th}$ activity ratio diagram for the products from Izu arc volcano. Data for basaltic and andesitic products (from Fuji, Izu-Oshima, Miyake-jima and Hachijojima volcanoes) are taken from [9], and those for rhyolitic products (from Niijima, Kozu-shima and Higashi Izu volcanoes) are taken from [11].

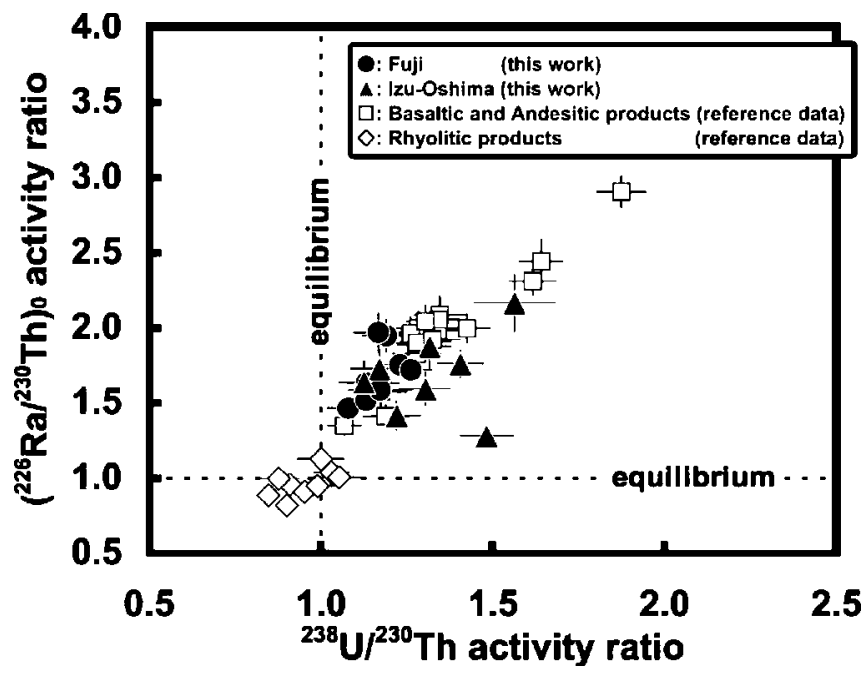

Fig. 3. $\left({ }^{226} \mathrm{Ra} /{ }^{230} \mathrm{Th}\right)_{0}-\left({ }^{238} \mathrm{U} /{ }^{230} \mathrm{Th}\right)$ activity ratio diagram for the products from Izu arc volcanoes. Data for rhyolitic products (from Niijima, Kozu-shima and Higashi Izu volcanoes) are taken from [14]. Data for basaltic and andesitic products (from the 1707 eruption of Fuji volcano, and from the 1986 eruption of Izu-Oshima volcano) from [12] and [13] are included.

earth crust, where ${ }^{238} \mathrm{U}-{ }^{230} \mathrm{Th}$ and ${ }^{230} \mathrm{Th}-{ }^{226} \mathrm{Ra}$ are in equilibrium, heated by the basaltic magma of high temperature [21].

Fig. 3 shows positive correlations between ${ }^{238} \mathrm{U} /{ }^{230} \mathrm{Th}$ activity ratio and $\left({ }^{226} \mathrm{Ra} /{ }^{230} \mathrm{Th}\right)_{0}$ activity ratio in the basaltic and andesitic products. The correlation suggests that the ${ }^{226} \mathrm{Ra}$ excess over ${ }^{230} \mathrm{Th}$ in the products may also be resulted by the addition of $\mathrm{U}$ - and Ra-rich fluids derived from the subducting slab by dehydration. Assuming that ${ }^{226} \mathrm{Ra}$ excess over ${ }^{230} \mathrm{Th}$ was generated at the magma genesis, the time scale from the magma genesis to the eruption, including the melting of the mantle wedge, magma storage and magmatic differentiation from basalt to anesite is less than $8.0 \times 10^{3} \mathrm{y}$. 


\section{Conclusion}

Basaltic magmas from historical eruptions of Fuji and IzuOshima volcanoes showed ${ }^{230} \mathrm{Th}<{ }^{238} \mathrm{U}$ and ${ }^{226} \mathrm{Ra}>{ }^{230} \mathrm{Th}$ disequilibria which is common characteristic to the basaltic and andesitic magmas from Izu arc volcanoes. The ${ }^{226} \mathrm{Ra}>$ ${ }^{230} \mathrm{Th}$ disequilibrium observed in the magma implies that the time scale from the magma genesis to the eruption is less than $8000 \mathrm{y}$.

Acknowledgment. The authors gratefully acknowledge Prof. T. Nakamura, Meiji University, for his continuous encouragement and for offering them the volcanic rock samples from younger Fuji volcano (80002 AD, 864-866 AD, 937 AD and 1033 AD), and Dr. K. Nakayama, Meiji University, for his cooperation in the X-ray fluorescence analysis and Dr. T. Ohta, Kyoto University, and Mr. H. Takahashi, The University of Tokyo, for the cooperation in sampling the products from Izu-Oshima volcano. They also thank anonymous reviewers for their important comments on the manuscript and thank Prof. Dr. H. Nitsche for the editorial help and patience.

\section{References}

1. Hawkesworth, C., George, R., Turner, S.: Time scales of magmatic processes. Earth Planet. Sci. Lett. 218, 1 (2004).

2. Tatsumi, Y.: Migration of fluid phases and genesis of basalt magmas in subduction zones. J. Geophys. Res. 94, 4697 (1989).

3. Turner, S., Bourbon, B., Gill, J.: Insights into magma genesis at convergent margins from U-series isotopes. Rev. Mineral. Geochem. 52, 255 (2003).

4. Peate, D. W., Hawkesworth, C. J.: Rev. Geophys. 43, 1 (2005).

5. Brenan, J. M., Shaw, H. F., Ryerson, F. J., Phinney, D. L.: Mineralaqueous fluid partitioning of trace elements at $900{ }^{\circ} \mathrm{C}$ and 2.0 GPa: constraints on the trace element chemistry of mantle and deep crustal fluids. Geochim. Cosmochim. Acta 59, 3331 (1995).

6. Keppler, H.: Constraints from partitioning experiments on the composition of subduction-zone fluids. Nature 380, 237 (1996).

7. Yokoyama, T., Kobayashi, K., Kuritani, T., Nakamura, E.: Mantle metasomatism and rapid ascent of slab components beneath island arcs: evidence from ${ }^{238} \mathrm{U}-{ }^{230} \mathrm{Th}-{ }^{226} \mathrm{Ra}$ disequilibria of Miyakejima volcano, Izu arc, Japan. Geochim. Cosmochim. Acta 70, 2885 (2006).
8. Yokoyama, T., Kuritani, T., Kobayashi, K., Nakamura, E.: Geochemical evolution of a shallow magma plumbing system during the last 500 years, Miyakejima volcano, Japan: constraints from ${ }^{238} \mathrm{U}-{ }^{230} \mathrm{Th}-{ }^{226} \mathrm{Ra}$ systematics. J. Geophys. Res. 108, doi:10.1029/2002JB002103 (2003).

9. Kurihara, Y., Takahashi, M., Sato, J.: ${ }^{238} \mathrm{U}-{ }^{230} \mathrm{Th}$ radioactive disequilibria in the volcanic products from Izu arc volcanoes, Japan. Radioisotopes 56, 795 (2007).

10. Fukuda, S., Nakai, S., Niihori, K., Tsukui, M., Nakada, S., Fujii, T., Tani, K.: ${ }^{238} \mathrm{U}-{ }^{230} \mathrm{Th}$ radioactive disequilibrium in the northern Izu arc: $\left({ }^{230} \mathrm{Th} /{ }^{232} \mathrm{Th}\right)$ in the sub-arc mantle. Geochem. J. 42, 461 (2008).

11. Takahashi, M., Kurihara, Y., Sato, J.: ${ }^{230} \mathrm{Th} /{ }^{238} \mathrm{U}$ activity ratios in rhyolite from Izu arc volcanoes. Radioisotopes 58, 93 (2009).

12. Kurihara, Y., Takahashi, M., Sato, J.: ${ }^{238} \mathrm{U}-{ }^{230} \mathrm{Th}-{ }^{226} \mathrm{Ra}$ radioactive disequilibria in the products from 1707 eruption of Fuji volcano, Japan. Radioisotopes 57, 471 (2008).

13. Kurihara, Y., Takahashi, M., Sato, J.: ${ }^{238} \mathrm{U}-{ }^{230} \mathrm{Th}-{ }^{226} \mathrm{Ra}$ radioactive disequilibria in the lava flows of the 1986 eruption from Izu-Oshima volcano, Japan. Radioisotopes 58, 13 (2009).

14. Takahashi, M., Kurihara, Y., Sato, J.: ${ }^{230} \mathrm{Th} /{ }^{238} \mathrm{U}$ and ${ }^{226} \mathrm{Ra} /{ }^{230} \mathrm{Th}$ activity ratios in rhyolite from Izu arc volcanoes. Radioisotopes 58, 599 (2009).

15. Nakayama, K., Nakamura, T.: X-ray fluorescence analysis of rare earth elements in rocks using low dilution glass beads. Anal. Sci. 21, 815 (2005).

16. Takahashi, M., Kurihara, Y., Sato, J.: A simple source preparation for alpha-ray spectrometry of uranium and thorium isotopes. Radioisotopes 56, 737 (2007).

17. Lee, M. H., Lee, C. W.: Preparation of alpha-emitting nuclides by electrodeposition. Nucl. Instrum. Methods A 447, 593 (2000).

18. Uchiumi, S., Uto, K., Shibata, K.: K-Ar ages of rock reference materials. Mass Spectrosc. 37, 375 (1989) [in Japanese with English abstract].

19. Turner, S., Hawkesworth, C., Rogers, N., Bartlett, J., Worthington, T., Hergt, J., Pearce, J., Smith, I.: ${ }^{238} \mathrm{U}-{ }^{230} \mathrm{Th}$ disequilibria, magma petrogenesis, and flux rates beneath the depleted TongaKermadec island arc. Geochim. Cosmochim. Acta 61, 4855 (1997).

20. Elliott, T., Plank, T., Zindler, A., White, W., Bourdon, B.: Element transport from slab to volcanic front at the Mariana arc. J. Geophys. Res. 102, 14991 (1997).

21. Tamura, Y., Tatsumi, Y.: Remelting of an andesitic crust as a possible origin for rhyolitic magma in oceanic arcs; an example from the Izu-Bonin arc. J. Petrol. 43, 1029 (2002). 